\title{
A revision of Medon. XI. Five new species, additional records, and the first confirmed records from the Oriental region (Coleoptera: Staphylinidae: Paederinae)
}

With 30 figures and 1 map

\author{
VOLKER ASSINg ${ }^{1}$
}

\author{
${ }^{1}$ Gabelsbergerstraße 2, 30163 Hannover, Germany. - vassing.hann@t-online.de \\ Published on 2018-08-01 \\ DOI: 110.21248 /contrib.entomol.68.1.069-081'
}

\section{Abstract}

Five species of the paederine genus Medon Stephens, 1833 from the East Palaearctic and Oriental regions are described and illustrated: Medon arunicus spec. nov. (East Nepal: Arun valley) and M. acutapicalis spec. nov. (East Nepal: Theratum district) of the M. apicalis group; M. sundaicus spec. nov. (Indonesia: Java, Sulawesi) and M. sabahicus spec. nov. (Malaysia: Sabah) of the M. ferrugineus group; M. emeianus spec. nov. (China: Emei Shan) of the M. profundus group. Medon sundaicus and M. sabahicus represent the first confirmed records of the genus from the Oriental region. Additional records of 32 species and subspecies are reported, among them several new country records. Medon is now represented in the Palaearctic region by five species groups and 86 confirmed species, 23 of which are distributed in the East Palaearctic region.

\section{Nomenclatural acts}

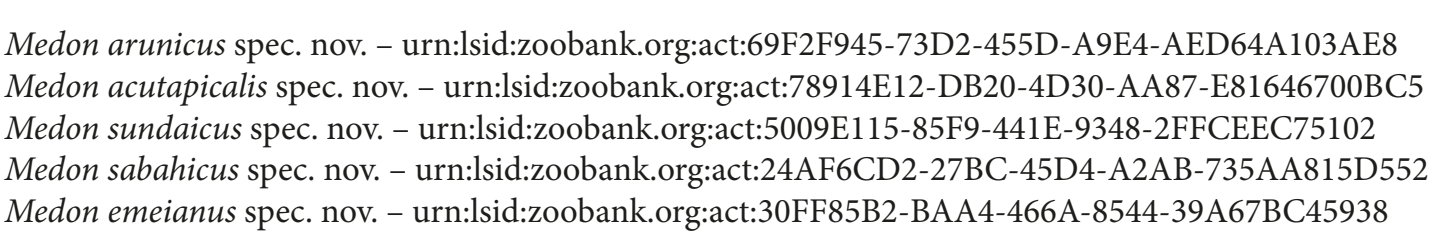

\section{Key words}

Coleoptera, Staphylinidae, Paederinae, Medon, Palaearctic region, Oriential region, Nepal, taxonomy, new species, new records

\section{Zusammenfassung}

Fünf Arten der Gattung Medon Stephens, 1833 (Paederinae) aus der Ostpaläarktis und der Orientalis werden beschrieben und abgebildet: Medon arunicus spec. nov. (Ost-Nepal) und M. acutapicalis spec. nov. (Ost-Nepal) aus der M. apicalis-Gruppe, M. sundaicus spec. nov. (Indonesien: Java, Sulawesi) und M. sabahicus spec. nov. (Malaysia: Sabah) aus der M. ferrugineus-Gruppe sowie M. emeianus spec. nov. (China: Emei Shan) aus der M. profundusGruppe. Mit Medon sundaicus und M. sabahicus wird die Gattung erstmals für die Orientalis bestätigt. Weitere 
Nachweise von 31 Arten und Unterarten werden gemeldet, darunter mehrere Erstnachweise. Medon ist derzeit in der Paläarktis mit fünf Artengruppen und 86 revidierten Arten vertreten, von denen 23 in der Ostpaläarktis verbreitet sind.

\section{Introduction}

According to recent revisions, the genus Medon STEPHENS, 1833 was previously represented in the Palaearctic region sensu Schülke \& Smetana (2015) by 81 species, one of them with five subspecies, in five species groups. Four of these species and one subspecies are of doubtful identity (Assing 2004a-b, 2005, 2006, 2007a-b, 2009, 2010, 2013, 2014). Two additional species were described recently from the Greek island Karpathos and from Japan by Assing (2016) and Shibata \& Fujimoto (2017), respectively. For details on the zoogeography, species groups, diversity, and an updated catalogue of the Palaearctic Medon fauna see Assing (2013). So far, all the revised Medon species from the Oriental region have proved to belong to other genera of Medonina.

Since the latest contribution, more material from various collections has been examined. In all, 36 species and subspecies were identified, including two new species from Nepal, one from China, and two from Indonesia and Malaysia, the first confirmed records of the genus from the Oriental region.

\section{Material and methods}

The material treated in this study is deposited in the following public institutions and private collections:

BMNH The Natural History Museum, London (R. G. Booth, M. Barclay)

CAS Chinese Academy of Sciences, Beijing

HNHM Hungarian Natural History Museum, Budapest (Gy. Makranczy)

MHNG Muséum d'Histoire Naturelle, Genève (G. Cuccodoro)

MNB Museum für Naturkunde, Berlin (including coll. Schülke; J. Frisch, M. Schülke, J. Willers)

NME Naturkundemuseum Erfurt (M. Hartmann, assisted by W. Apfel)

cApf private collection Wolfgang Apfel, Eisenach

cAss author's private collection

cFel private collection Benedikt Feldmann, Münster

cKoc private collection Matúš Kocian, Praha

cPüt private collection Andreas Pütz, Eisenhüttenstadt

cRou private collection Guillaume de Rougemont, Oxford

cSha private collection Alexey Shavrin, Daugavpils

cSme private collection Aleš Smetana, Ottawa
The morphological studies were conducted using a Stemi SV 11 microscope (Zeiss Germany) and a Jenalab compound microscope (Carl Zeiss Jena). The images were created using a photographing device constructed by Arved Lompe (Nienburg) and CombineZ software, as well as a digital camera (Nikon Coolpix 995). The map was created using MapCreator 2.0 (primap) software.

Body length was measured from the anterior margin of the mandibles (in resting position) to the abdominal apex, the length of the forebody from the anterior margin of the mandibles to the posterior margin of the elytra, head length from the anterior margin of the frons to the posterior constriction of the head, elytral length at the suture from the apex of the scutellum to the posterior margin of the elytra, and the length of the aedeagus from the apex of the ventral process to the base of the aedeagal capsule. The "parameral" side (i.e., the side where the sperm duct enters) is referred to as the ventral, the opposite side as the dorsal aspect.

\section{Species descriptions and additional records}

\section{Medon apicalis group \\ Medon apicalis (KRAATZ, 1857) \\ (Map 1)}

Material examined: Hungary: 2 exs., Bács-Kiskun, Kunpeszér, car-net, 27.IV.2005, leg. Merkl \& Vörös (HNHM); 1 ex., Budapest, Tündér-hegy, car-net, 2.V.2002, leg. Merkl (HNHM); 1 ex., Nógrád, Ipolytarnóc, Borókás-árok, car-net, 29.VII.2001, leg. Merkl (cAss). Croatia: 1 ㅇ, Zadar region, SE Pag, Rtina Miletici, $44^{\circ} 19^{\prime} \mathrm{N}, 15^{\circ} 16^{\prime} \mathrm{E}, 25 \mathrm{~m}, 30 . \mathrm{VIII} .2014$, leg. Frenzel (NME). Turkey: 3 exs., Istanbul, Belgrad Ormanı, near Ikinci,

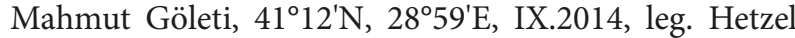
(cFel, cAss).

Comment: The above record from Turkey considerably expands the known distribution of M. apicalis southeastwards. The species was recently also recorded from Greece (Corfu) for the first time (Assing et al. 2018). Based on previously available material, the distribution type had been categorized as expansive Atlanto-Mediterranean (Assing 2006), a hypothesis that is no longer supported by the recent records from the southern Balkans and from Turkey. Based on currently available data, the distribution of $M$. apicalis is of the Holo-Mediterranean type (Map 1). There are, however, 
significantly more records from the West Mediterranean than from the East Mediterranean region. Since most of the material was collected on the wing, usually with carnets and flight interception traps, this observation could be explained with a sampling bias. Another explanation could be that M. apicalis is less common in the East Mediterranean as a result of competition with other species of the M. apicalis group, as is evidently the case in Italy (competition with M. perniger CoIfFAIT, 1978). The specimen from Istanbul was collected together with M. maronitus.

\section{Medon maronitus (SAULCY, 1865)}

Material examined: Turkey: 9 exs., Istanbul, Belgrad Ormanı, near Ikinci, Mahmut Göleti, $41^{\circ} 12^{\prime} \mathrm{N}, 28^{\circ} 59^{\prime} \mathrm{E}$, IX.2014, leg. Hetzel (cFel, cAss).

Armenia: $1 \sigma^{\star}$, Dashtakar env., bank of Vedi river, $39.92^{\circ} \mathrm{N}$, $44.78^{\circ} \mathrm{E}, 1000$ m, 18.V.2015, leg. Kocian (cKoc).
Georgia: 1 ex., Kachetia, Tsiv-Gombori mountain range, $5 \mathrm{~km} \mathrm{~W}$ Telavi, 41 ${ }^{\circ} 54^{\prime} \mathrm{N}, 4^{\circ} 24^{\prime} \mathrm{E}, 1090 \mathrm{~m}$, beech forest, 8.VII.2015, leg. Pütz (cPüt); 1 ex., Kachetia, TsivGombori mountain range, $3 \mathrm{~km} \mathrm{~N}$ Sagarejo, $41^{\circ} 45^{\prime} \mathrm{N}$, $44^{\circ} 19^{\prime} \mathrm{E}, 930 \mathrm{~m}$, beech forest, 30.VI.2015, leg. Pütz (cAss).

Iran: Gilan: 6 exs., S Astara, W Lomir, $38^{\circ} 13^{\prime} \mathrm{N}, 48^{\circ} 53^{\prime} \mathrm{E}$, 100 m, 10.X.2011, leg. Frisch (MNB, cAss). Ilam: 1 ex.,

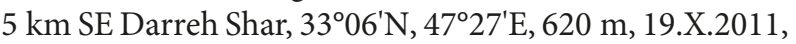
leg. Frisch (MNB); 4 exs., S Hashtpar, Asalem, $37^{\circ} 42^{\prime} \mathrm{N}$, $48^{\circ} 53^{\prime} \mathrm{E}, 110 \mathrm{~m}$, 9.X.2011, leg. Frisch (MNB, cAss); 1 ex., pass Khalkhal-Asalem, $37^{\circ} 36^{\prime} \mathrm{N}, 48^{\circ} 40^{\prime} \mathrm{E}, 2070 \mathrm{~m}$, 13.X.2011, leg. Frisch (MNB).

Comment: The vast distribution ranges from the southern Balkans to Middle Asia and the Middle East (Assing 2009). The above male from Armenia represents a new country record.

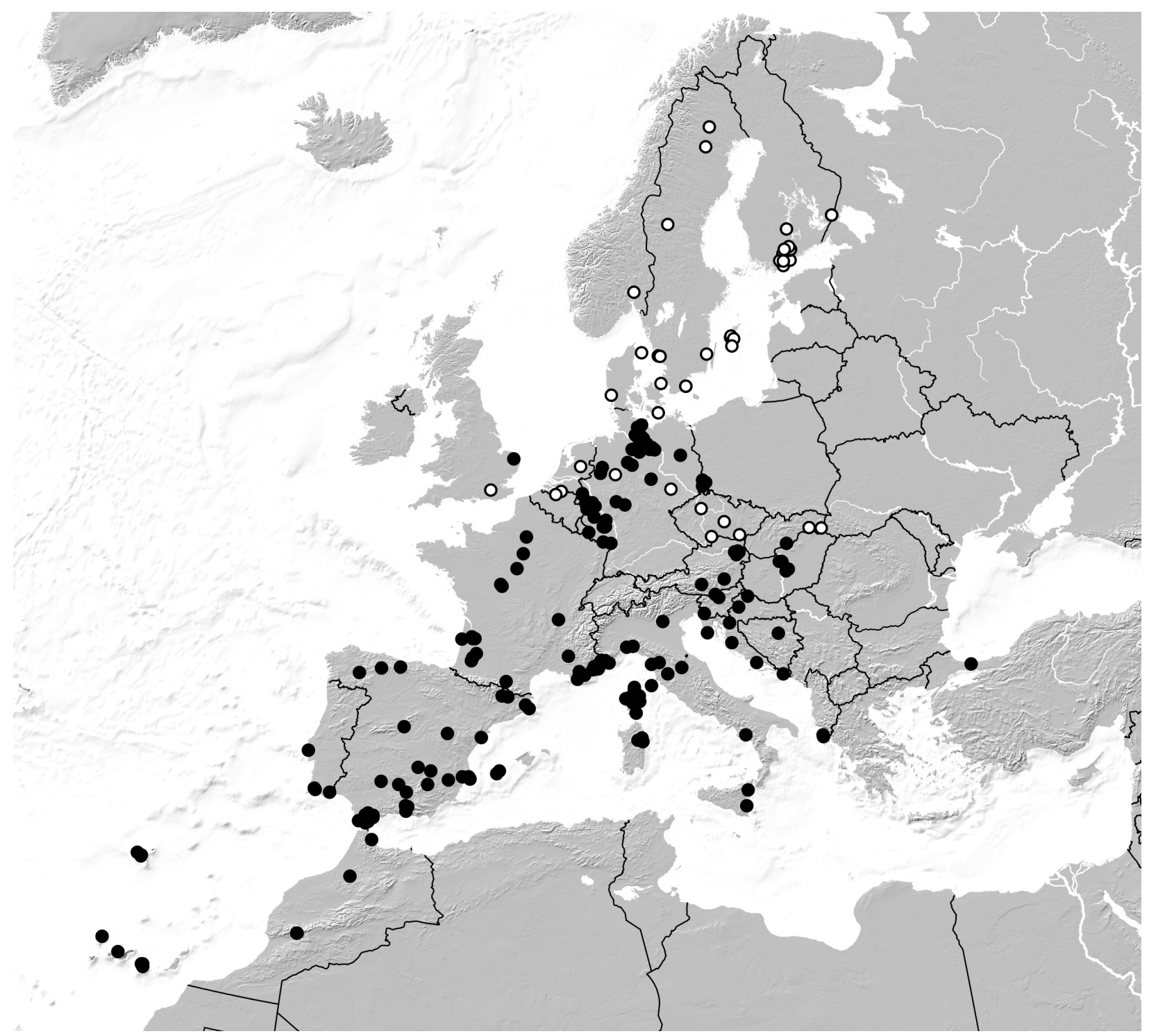

Map 1: Distribution of Medon apicalis in the West Palaearctic region, based on revised (black circles) and selected literature records (white circles). 


\section{Medon petrochilosi CoIfFAIt, 1970}

Material examined: Greece: $10^{*}, 2$ 우, Pelopónnisos, $\mathrm{S}$ Diakopto, road to Kalavrita, $38^{\circ} 08-10^{\prime} \mathrm{N}, 22^{\circ} 14-17^{\prime} \mathrm{E}$, 50-500 m, car-net, 6.IV.2016, leg. Schülke (MNB, cAss).

Comment: The known distribution ranges from Croatia and Macedonia southwards to the southern Peloponnisos. For a map see Assing (2013).

\section{Medon guignoti ColfFalt, 1987}

Material examined: Greece: $1 \sigma^{x}$, Evia, road Meto-

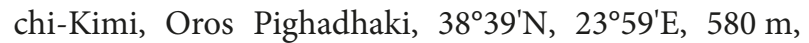
7.VI.2012-8.VI.2014, leg. Giachino \& Vailati (cAss).

Comment: The distribution of this rarely found species is confined to the southern Balkans (Greece, Macedonia, Bulgaria). For a map see Assing (2013).

\section{Medon excavatus Assing, 2013}

Material examined: Greece: $1 \sigma^{\star}$, Pelopónnisos, Ahaia, Oros Skepasto, Plataniotisa, Agios Konstantinos, $38^{\circ} 05^{\prime} \mathrm{N}, 22^{\circ} 05^{\prime} \mathrm{E}, 1040 \mathrm{~m}$, subterranean pitfall trap, 20.V.2011-2.VI.2012, leg. Giachino \& Vailati (cAss); $1 \sigma^{\star}$, Pelopónnisos, Aroania, E Kalavrita, road to ski resort, $38^{\circ} 00-01^{\prime} \mathrm{N}, 22^{\circ} 09-11^{\prime} \mathrm{E}, 1250-1500 \mathrm{~m}$, car-net, 5.IV.2016, leg. Schülke (MNB).

Comment: This recently described species has been recorded only from the Peloponnisos, Greece (Assing 2013).

\section{Medon gratus CAMERON, 1931}

Material examined: Pakistan: 10 exs., Swat, Marghuzar, 1300 m, 8.V.1983, leg. Besuchet \& Löbl (MHNG, cAss); 1 ex., Swat, Malam Jabba, 2500-2600 m, 18.V.1983, leg. Besuchet \& Löbl (cAss).

Comment: Medon gratus was previously known from North India and Afghanistan (Assing 2013). The above specimens represent the first records from Pakistan.

\section{Medon dhaulagiricus Assing, 2013}

Material examined: Nepal: 9 exs., SW-Dhaulagiri, Maraini, $28^{\circ} 31^{\prime} \mathrm{N}, 83^{\circ} 16^{\prime} \mathrm{E}, 2400-2800 \mathrm{~m}, 11 . \mathrm{V} .2013$, leg. Schmidt (NME, cAss).

Comment: This recently described species was previously known only from the type locality (Marang Khola valley) (Assing 2013).

\section{Medon inexcisus Assing, 2013}

Material examined: Nepal: 8 exs., Kaski, Bachhar Kharka, NE Sikles, $28^{\circ} 23^{\prime} \mathrm{N}, 84^{\circ} 08^{\prime} \mathrm{E}, 2200-2400 \mathrm{~m}$, 15.IX.2013, leg. Hagge \& Schmidt (NME, cAss).

Comment: Medon excisus is apparently endemic to the southeastern Annapurna range (Assing 2013).

\section{Medon bifidus Assing, 2013}

Material examined: Nepal: $1 \sigma^{\top}$, Manaslu, E-slope of Ngali Khola valley, $28^{\circ} 22^{\prime} \mathrm{N}, 84^{\circ} 29^{\prime} \mathrm{E}, 2000-2300 \mathrm{~m}$, 15.V.2005, leg. Schmidt (NME).

Comment: The above male was collected together with the type specimens.

\section{Medon manas/uensis Assing, 2010}

Material examined: Nepal: 3 ㅇ ㅇ, SE-Manaslu, Gupchi Danda, $28^{\circ} 09^{\prime} \mathrm{N}, 84^{\circ} 47^{\prime} \mathrm{E}, 2900-3200 \mathrm{~m}, 21 . V .2006$, leg. Schmidt (NME).

Comment: The identification of the above females is somewhat tentative and mainly based on the vicinity of the above locality to the type locality.

\section{Medon corniger Assing, 2013}

Material examined: Nepal: $2 \sigma^{*} \sigma^{*}$, Manaslu, E-slope of Ngali Khola valley, $28^{\circ} 22^{\prime} \mathrm{N}, 84^{\circ} 29^{\prime} \mathrm{E}, 2000-2300 \mathrm{~m}$, 15.V.2005, leg. Schmidt (NME, cAss).

Comment: The known distribution of $M$. corniger ranges from the Manaslu range in Central Nepal to Yunnan (China) (Assing 2013).

\section{Medon arunicus spec. nov.

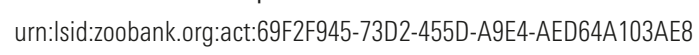 (Figs 1-6)}

Type material: Holotype $o^{\star}$ : "E-NEPAL, Arun Valley, W above Tashigaon, 25-2700 m, 26.-27.V.2014, 27³6'33"N, 87²13'28,E, leg. Schmidt / Holotypus ơ Medon arunicus sp. n., det. V. Assing 2015" (NME). Paratypes: $1 \sigma^{*}$, 1 ex.: same data as holotype (NME, cAss); $10^{\star}, 2$ 우: "E-NEPAL, Arun Valley, env. Tashigaon, 2200-2400 m, 12.+28.-29.V.2014, 27 $37^{\circ} \mathrm{N}, \quad 87^{\circ} 14^{\prime} \mathrm{E}$, leg. Schmidt” (NME, cAss).

Etymology: The specific epithet is an adjective derived from Arun, the name of the valley where the type specimens were discovered. 


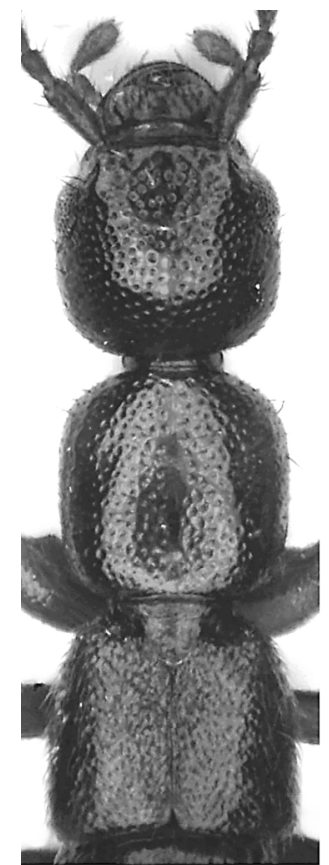

1

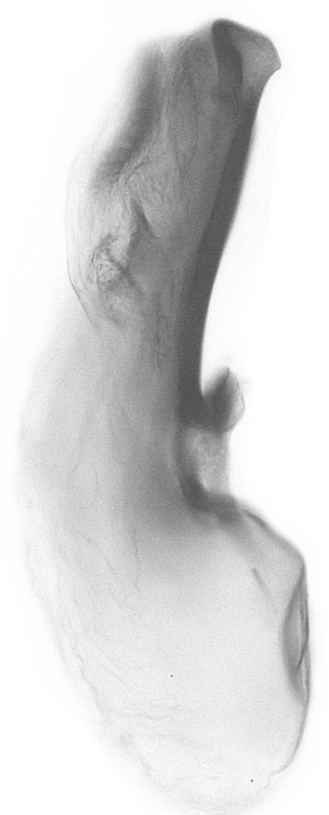

5

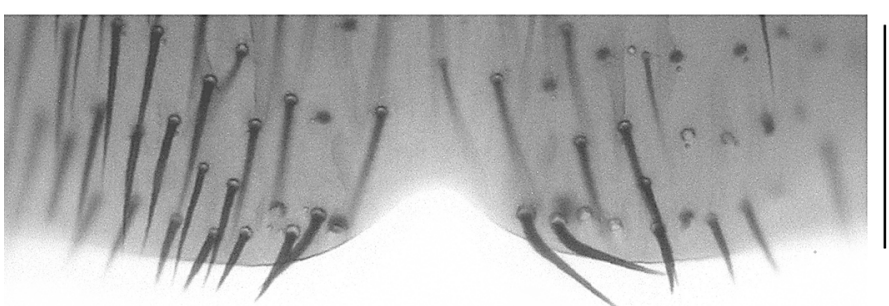

3

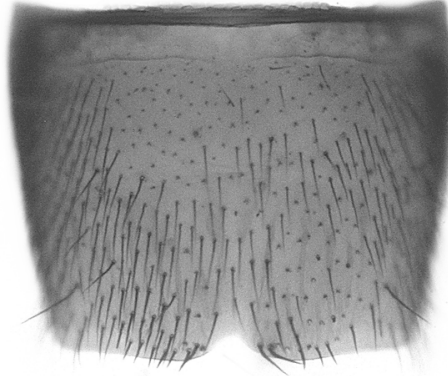

2

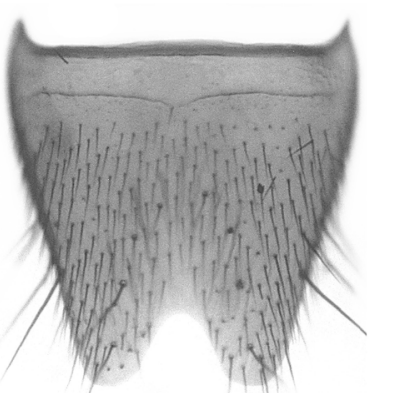

4

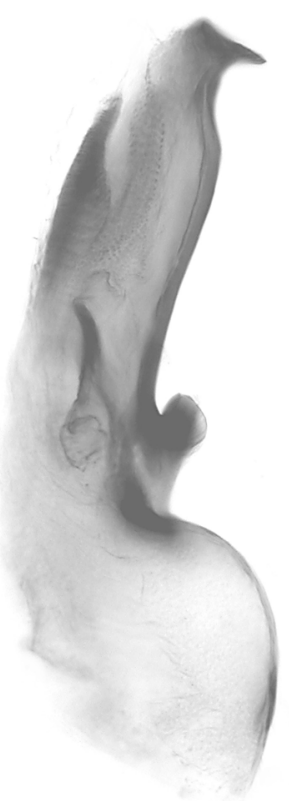

11

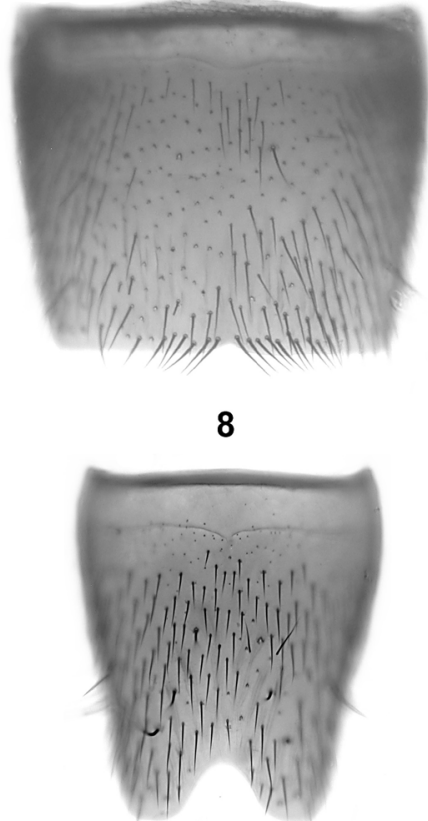

10

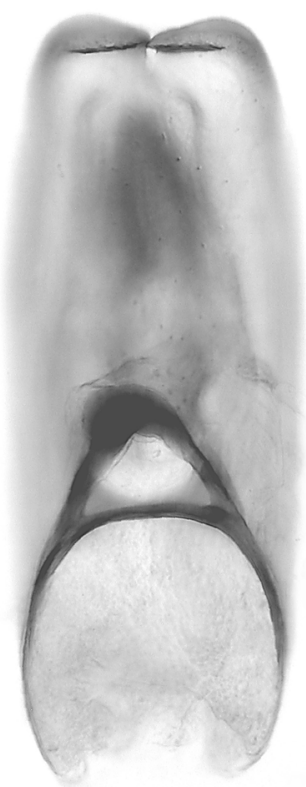

12

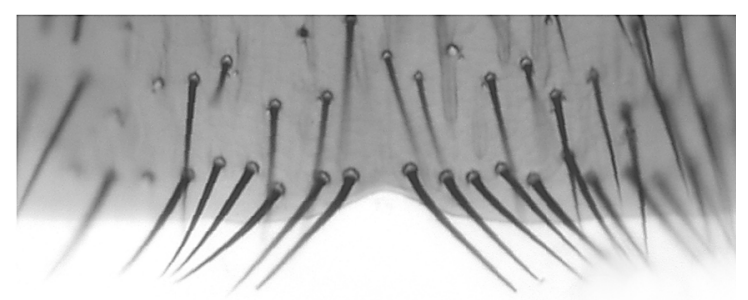

9

Figs 1-12: Medon arunicus spec. nov. (1-6) and M. acutapicalis spec. nov. (7-12): forebody $(1,7)$; male sternite VII $(2,8)$; posteromedian portion of male sternite VII $(3,9)$; male sternite VIII $(4,10)$; median lobe of aedeagus in lateral and in ventral view $(5-6$, 11-12). Scale bars: 1, 7: $1.0 \mathrm{~mm} ; 2,4,8,10: 0.5 \mathrm{~mm} ; 5-6,11-12: 0.2 \mathrm{~mm} ; 3,9: 0.1 \mathrm{~mm}$. 
Description: Body length 4.0-4.7 mm; length of forebody $2.2-2.3 \mathrm{~mm}$. Coloration: body blackish-brown to blackish; legs and antennae brown to dark-brown.

Head (Fig. 1) approximately as broad as long; punctation dense and rather coarse, slightly less dense in median dorsal portion; interstices without microsculpture and, except for median dorsal portion, distinctly narrower than diameter of punctures. Eyes of moderate size and moderately convex, approximately 0.7 times as long as postocular region in dorsal view.

Pronotum (Fig. 1) approximately as broad as long and slightly broader than head; punctation about as dense as that of head, but slightly less coarse; midline narrowly impunctate; interstices without microsculpture.

Elytra (Fig. 1) short, 0.70-0.75 times as long as pronotum; punctation dense and fine, rather weakly defined. Hind wings completely reduced. Metatarsomere I nearly as long as the combined length of II and III.

Abdomen slightly broader than elytra; punctation dense and very fine; interstices with shallow microreticulation; posterior margin of tergite VII without palisade fringe. $\sigma^{*}$ : sternite VII (Figs 2-3) distinctly transverse, posterior margin with broadly $\mathrm{V}$-shaped median excision in the middle, on either side of this excision with two slightly longer and stouter black setae; sternite VIII shaped as in Fig. 4; aedeagus approximately $0.5 \mathrm{~mm}$ long and shaped as in Figs 5-6.

Comparative notes: Based on the male primary and secondary sexual characters, $M$. arunicus belongs to the M. apicalis group and is closely allied to M. manasluensis Assing, 2010 and related species. The aedeagus and the shapes and chaetotaxy of the male sternites VII and VIII are most similar to those of M. schawalleri Assing, 2013 from Solukhumbu, which too is an endemic of East Nepal, but differs from the new species by paler coloration (head and pronotum dark-brown; elytra brown; legs dark-yellowish), distinctly sparser and finer punctation of the head and pronotum, smaller and less convex eyes, the shape and chaetotaxy of the male sternite VII (posterior excision narrower, setae on either side of this excision longer, but not stouter than other setae), the shape of the male sternite VIII (posterior excision broader and less deep), and by the shape of the aedeagus (apices slightly longer and less stout). For illustrations of $M$. schawalleri see Assing (2013).

Distribution and natural history: The new species was collected in two close localities near Tashigaon in the Arun valley, East Nepal, at altitudes between 2200 and $2700 \mathrm{~m}$.

\section{Medon acutapicalis spec. nov.

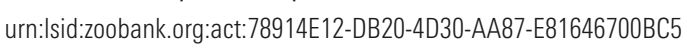 (Figs 7-12)}

Type material: Holotype $\sigma^{*}$ : "NEPAL, E, Therathum distr., Basantapur, 2650-2700 m, 28.-29.V.2016, leg. J. Schmidt, $27^{\circ} 10^{\prime} 21^{\prime \prime} \mathrm{N}, 87^{\circ} 25^{\prime} 14^{\prime \prime E} /$ collection Naturkundemuseum Erfurt / Holotypus o Medon acutapicalis sp. n., det. V. Assing 2016" (NME). Paratypes: 18 exs.: same data as holotype (NME, cAss).

Etymology: The specific epithet (adjective) alludes to the acute apex of the ventral process in lateral view.

Description: Body length 3.3-5.2 mm; length of forebody 1.9-2.3 mm. Coloration: body dark-brown to blackishbrown, with the pronotum and elytra usually slightly paler; legs yellowish-brown to pale-brown; antennae reddish with antennomere I usually slightly darker and the apical antennomeres more or less extensively paler. Elytra approximately 0.65 times as long as pronotum (Fig. 7). Other external characters as in M. arunicus. $\mathrm{o}^{\star}$ : sternite VII (Figs 8-9) moderately transverse, approximately 1.2 times as broad as long, posterior margin with small and very shallow median excision in the middle, on either side of this excision with a row of 7-9 long and moderately stout black setae; sternite VIII shaped as in Fig. 10; aedeagus approximately $0.5 \mathrm{~mm}$ long and shaped as in Figs 11-12.

Comparative notes: Like the geographically close M. arunicus, M. acutapicalis belongs to the M. apicalis group and is closely allied to M. manasluensis and related species. It is distinguished from all the species allied to M. manasluensis by the shape of the aedeagus and by the shape and chaetotaxy of the posterior margin of the male sternite VII. It additionally differs from $M$. arunicus by slightly paler coloration (particularly of the legs and antennae) and slightly shorter elytra.

Distribution and natural history: The type locality is situated in Therathum district, East Nepal, at an altitude of $2650-2700 \mathrm{~m}$. As can be inferred from the reduced hind wings and the pronounced local endemism of other species allied to M. manasluensis, M. acutapicalis probably has a restricted distribution.

\section{Medon brunneus group}

\section{Medon brunneus (ERICHSON, 1839)}

Material examined: France: 3 exs., Mercantour, N Sospel, NNE Col de Bruis, 435' $\mathrm{N}, 07^{\circ} 29^{\prime} \mathrm{E}, 735 \mathrm{~m}$, 15.VII.2009, leg. Schnitter \& Komposch (NME, cAss). Italy: Veneto: 2 exs., Valdobbiadene (TV), Pian de Farne, $45^{\circ} 56^{\prime} \mathrm{N}, 12^{\circ} 02^{\prime} \mathrm{E}, 1000 \mathrm{~m}, 26 . \mathrm{IX} .2013$, leg. Meybohm (cAss, MNB); 2 exs., Valdobbiadene (TV), Pianezze, $45^{\circ} 55^{\prime} \mathrm{N}, 12^{\circ} 01^{\prime} \mathrm{E}, 950 \mathrm{~m}, 4 . \mathrm{X} .2013$, leg. Meybohm (cAss, MNB); 2 exs., Valdobbiadene (TV), Strada S. Alberto, $45^{\circ} 54^{\prime} \mathrm{N}, 12^{\circ} 02^{\prime} \mathrm{E}, 450 \mathrm{~m}, 3 . X .2013$, leg. Meybohm (cAss, MNB); 2 exs., Monte Grappa (TV), Monte Tomba, $45^{\circ} 53^{\prime} \mathrm{N}, 11^{\circ} 52^{\prime} \mathrm{E}, 980 \mathrm{~m}, 6 . \mathrm{X} .2013$, leg. Meybohm (cAss, $\mathrm{MNB})$. 
Comment: The above records are within the known distribution of M. brunneus.

\section{Medon cauchoisi JARrIGE, 1949}

Material examined: Spain: 1 ex., Alicante, NW El Castell de Guadalest, $1 \mathrm{~km} \mathrm{~W}$ Beniarda, $38^{\circ} 41^{\prime} \mathrm{N}, 0^{\circ} 13^{\prime} \mathrm{W}$, 550 m, 25.XI.2013, leg. Forcke (cAss); 2 exs., Alicante, W Benigembla, Bco. de Malafi, $38^{\circ} 46^{\prime} \mathrm{N}, 0^{\circ} 12^{\prime} \mathrm{W}, 520 \mathrm{~m}$, 29.XI.2013, leg. Forcke (MNB).

Comment: The Atlanto-Mediterranean distribution of M. cauchoisi ranges from Northwest Africa across the Iberian Peninsula to Southwest France (Assing 2013).

\section{Medon semiobscurus (FAuvel, 1875)}

Material examined: Syria: 6 exs., Latakia province, $5 \mathrm{~km}$ S Kasab, pine forest, sifted, 5.VI.2010, leg. Kotán et al. (HNHM, cAss). Lebanon: $10^{\star}$, Rayfoun, ca. $33^{\circ} 58^{\prime} \mathrm{N}$, $35^{\circ} 42^{\prime} \mathrm{E}$, mixed oak forest, ca. $990 \mathrm{~m}$, pitfall trap, 28.II.-5. III.2017, leg. Reuter (cFel). Jordan: 4 exs., Irbid, Zubia, env. Zubia Cave, $32^{\circ} 26^{\prime} \mathrm{N}, 35^{\circ} 45^{\prime} \mathrm{E}, 840 \mathrm{~m}$, sifted from oak leaf litter, 2.III.2014, leg. Hetzel (cFel); 1 ex., same data, but $32^{\circ} 26^{\prime} \mathrm{N}, 35^{\circ} 46^{\prime} \mathrm{E}$ (cFel).

Comment: The above specimens from Syria are macropterous, dark-coloured, and have the head and pronotum distinctly microsculptured.

\section{Medon ferrugineus group}

\section{Medon dilutus pythonissa (SAULCY, 1865)}

Material examined: Greece: Mainland: 1 ex., AtikíPiréas, Oros Geránia, $1280 \mathrm{~m}$, subterranean pitfall trap, 30.V.2003-15.VI.2004, leg. Giachino \& Vailati (MNB); 2 exs., Atikí, Oros Kithairón, $38^{\circ} 11^{\prime} \mathrm{N}, 23^{\circ} 16^{\prime} \mathrm{E}, 1210 \mathrm{~m}$, subterranean pitfall trap, 22.V.2011-4.VI.2012, leg. Giachino \& Vailati (MNB). Crete: 3 exs., Therisos Gorge valley, $35.42^{\circ} \mathrm{N}, 23.99^{\circ} \mathrm{E}, 550-580 \mathrm{~m}$, sifting tree cavities and leaf litter, 23.IV.2015, leg. Kocian (cKoc, cAss); 1 ex., Lefka Ori, Omalos env., $35.36^{\circ} \mathrm{N}, 23.92^{\circ} \mathrm{E}$, sifted, 24.IV.2015, leg. Kocian (cKoc); 1 ex., Lefka Ori, Omalos env., $35.36^{\circ} \mathrm{N}, 23.92^{\circ} \mathrm{E}, 1100 \mathrm{~m}$, sifted, 20.IV.2015, leg. Kocian (cKoc); 4 exs., Aloides env., $35.37^{\circ} \mathrm{N}, 24.87^{\circ} \mathrm{E}$, $420 \mathrm{~m}$, tree cavities of Olea trees sifted, 18.IV.2015, leg. Kocian (cKoc).

Armenia: 1 ㅇ Lanjanist env., $39.86^{\circ} \mathrm{N}, 44.94^{\circ} \mathrm{E}, 1560 \mathrm{~m}$, 18.V.2015, leg. Kocian (cKoc); 1 + , Tatev env., Vorotan valley, $39.39^{\circ} \mathrm{N}, 46.25^{\circ} \mathrm{E}, 1300 \mathrm{~m}$, macchia, sifted, 24.V.2015, leg. Kocian (cAss). Georgia: 6 exs., Atskuri env., $41^{\circ} 45^{\prime} \mathrm{N}, 43^{\circ} 09^{\prime} \mathrm{E}, 1150 \mathrm{~m}, 20 . \mathrm{VI} .2013$, leg. Kocian (cKoc, cAss).
Comment: Medon dilutus pythonissa is by far the most common of the subspecies of M. dilutus (ERICHSON, 1839). Its Ponto-Mediterranean distribution ranges from the southern Balkans to the Middle East and the Caucasus region (Assing 2013).

\section{Medon dilutus quadriceps (WolLASTon, 1864)}

Material examined: Morocco: 1 + , S Gorges du Dades, 26.XII.1993, leg. Arndt \& Gröger (NME); $2 \sigma^{\star} \sigma^{\star}, 50 \mathrm{~km}$ S Marrakech, Asni env., 1300 m, leaf litter, 4.V.1998, leg. Erber (NME, cAss).

Comment: This subspecies is distributed in North Africa, Sicily, and the Canary Islands (Assing 2013).

\section{Medon rufiventris (NoRdmann, 1837)}

Material examined: Hungary: 1 ex., Békés, Szarvas, carnet, 3.-5.VIII.2000, leg. Merkl (HNHM). Greece: $1 o^{\star}$, Crete, Aloides env., $35.37^{\circ} \mathrm{N}, 24.87^{\circ} \mathrm{E}, 420 \mathrm{~m}$, tree cavities of Olea trees sifted, 18.IV.2015, leg. Kocian (cKoc). Turkey: 3 exs., Antalya, Alanya, 30 km E Beldibi, 1000 m, 1.IV.1996, leg. Kopetz (NME); 1 ex., Alanya, 12 km W Güzelbag, 600-900 m, 4.IV.1996, leg. Kopetz (cAss).

Comment: The distribution of $M$. rufiventris is of the Ponto-Mediterranean type (Assing 2013).

\section{Medon niger CAMERON, 1924}

Material examined: India: $1 \sigma^{\star}$, Uttarakhand, $1 \mathrm{~km}$ W Harsil, Bhagirathi river, $31^{\circ} 02^{\prime} \mathrm{N}, 78^{\circ} 43^{\prime} \mathrm{E}, 2460 \mathrm{~m}$, 15.IV.2012, leg. Anichtchenko (cSha).

Comment: Medon niger has been recorded from North India and Nepal (Assing 2013).

\section{Medon sundaicus spec. nov.

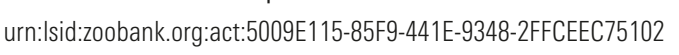 (Figs 13-21)}

Type material: Holotype $\sigma^{\star}$ : "Indonesia, Jawa Barat, Mount Halimun, 19-25.VIII.2009, leg. Majer / Holotypus ơ Medon sundaicus sp. n. det. V. Assing 2017” (cAss). Paratypes: 13 exs.: "SULAWESI TENGAH: Solato R., Taronggo, $1^{\circ} 45^{\prime} \mathrm{S}-121^{\circ} 40^{\prime} \mathrm{E}, 27-30 . i i i .1980$ / sieving / M.J.D. Brendell, B.M. 1980-280" (BMNH, cAss); 1 ex.: "SULAWESI TENGAH: Nr. Kolonodale, Gililana village, $1^{\circ} 55^{\prime}$ S-121 ${ }^{\circ} 22^{\prime}$ E. 7-8.ii. 1980 / rotting fruit / M.J.D. Brendell, B.M. 1980-280" (BMNH); 1 \%: "INDONESIA: SULAWESI UTARA, Dumoga-Bone N.P., February 1985. / Plot B, ca $300 \mathrm{~m}$, Lowland forest / Flight interception trap / R.Ent.Soc.Lond., Project Wallace, B.M. 1985- 


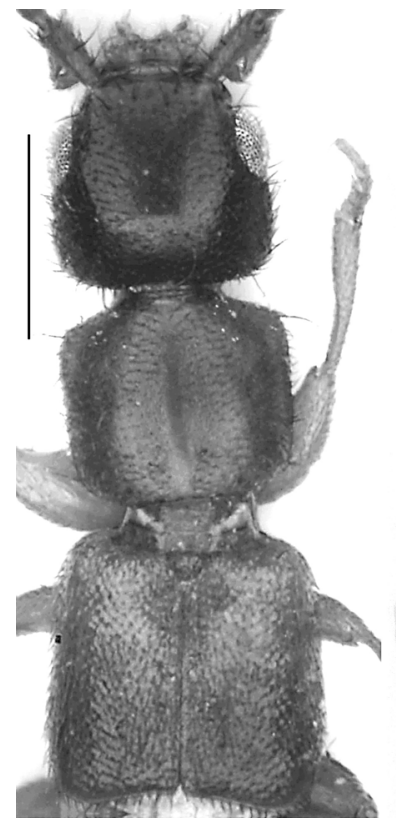

13

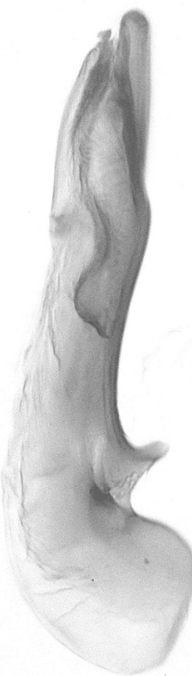

18

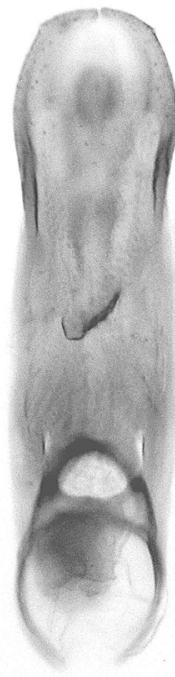

19

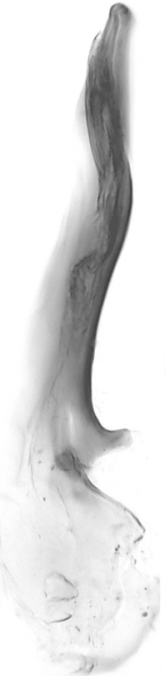

20

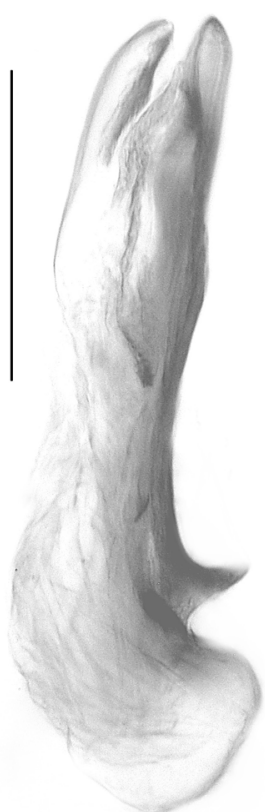

24

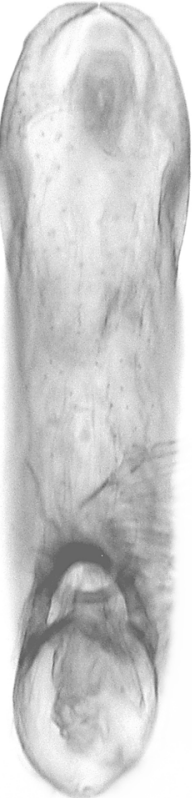

25

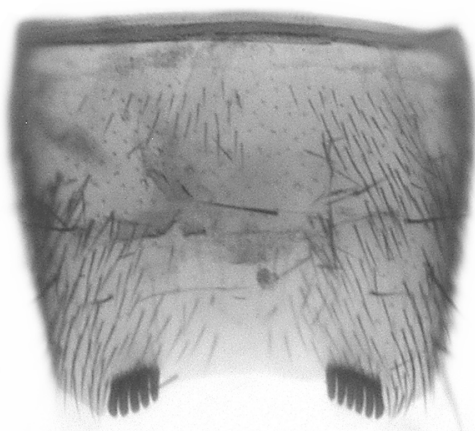

14

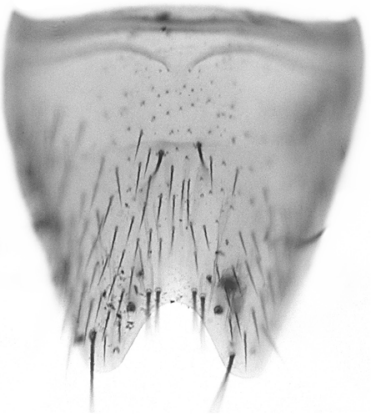

16

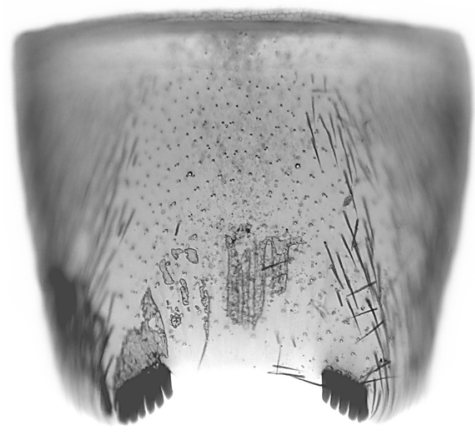

15

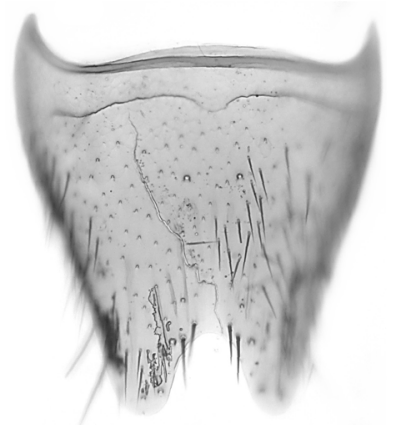

17
21

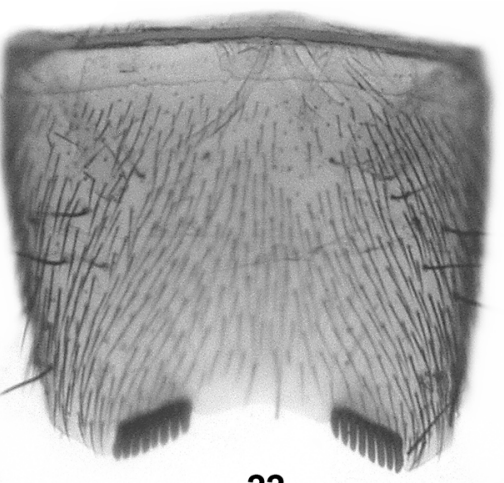

22

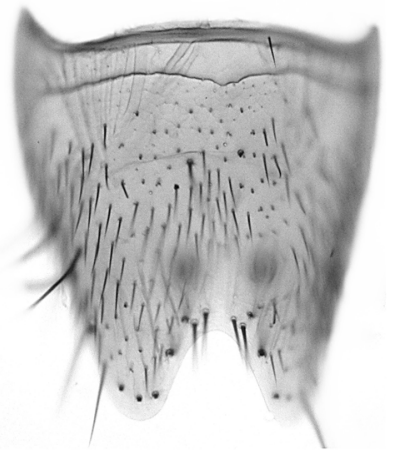

23

Figs 13-25: Medon sundaicus spec. nov. (13-21, 15, 17, 20-21: non-type male from Thailand) and M. sabahicus spec. nov. (22-25): forebody (13); male sternite VII $(14-15,22)$; male sternite VIII $(16-17,23)$; median lobe of aedeagus in lateral and in ventral view (18-21, 24-25). Scale bars: 13: $0.5 \mathrm{~mm}$; 14-25: $0.2 \mathrm{~mm}$.

10" (BMNH); 1 ㅇ: same data, but "Plot A, ca 200 m" (BMNH); 1 \%: "INDONESIA: SULAWESI UTARA, Dumoga-Bone N.P., 1985. / 'Edwards' Camp, Lowland forest, $664 \mathrm{~m}$, 26.iv.-4.vi. / Malaise trap / R.Ent.Soc. Lond., Project Wallace, B.M. 1985-10" (BMNH).

Additional material: $1 \sigma^{\top}$ [in poor condition]: “Thailand, Ban Sai Yok, 9.III.82, Rougemont” (cRou).
Comment: The above male from Thailand is not included in the type series. Its primary and secondary sexual characters (Figs 15, 17, 20-21) are practically identical to those of the males from Java and Sulawesi, but the microsculpture of the head is much less pronounced. Additional material from Thailand or adjacent regions is required to assess whether the populations from the Sunda Islands and Thailand are conspecific. 
Etymology: The specific epithet (adjective) alludes to the fact that this species is at present reliably known only from two of the Great Sunda Islands.

Description: Body length 3.0-4.0 mm; length of forebody 1.6-1.9 mm. Coloration: head brown to blackish-brown; pronotum reddish to dark-brown; elytra pale reddish, posteriorly often with an extensive dark spot of somewhat variable size and shape posteriorly, this spot not reaching suture, posterior margins, and humeral portion; abdomen reddish to reddish-brown, usually with at least the middle of tergites VI and VII somewhat infuscate; legs yellowish; antennae reddish.

Head (Fig. 13) weakly transverse, 1.05-1.10 times as broad as long, and with marked posterior angles; punctation very fine and moderately dense; interstices with distinct fine microreticulation. Eyes large and moderately convex, slightly shorter than postocular region in dorsal view.

Pronotum (Fig. 13) approximately 1.1 times as broad as long and about as broad as head, or slightly broader; punctation and microsculpture similar to those of head, or slightly more pronounced.

Elytra (Fig. 13) slightly shorter than pronotum; punctation dense and fine, but much more distinct than that of head and pronotum; interstices without microsculpture. Hind wings fully developed. Metatarsomere I slightly longer than II, distinctly shorter than the combined length of II and III.

Abdomen slightly narrower than elytra; punctation fine, very dense on anterior and somewhat less dense on posterior tergites; interstices with pronounced microreticulation; posterior margin of tergite VII with palisade fringe.

$\sigma^{\star}$ : sternite VII (Figs 14-15) moderately transverse, posterior margin with broad and pronounced concavity, on either side with a comb of 5-6 palisade setae; sternite VIII (Figs 16-17) with a rather large posterior excision of subtriangular shape; aedeagus (Figs 18-21) $0.42-0.46 \mathrm{~mm}$ long and slender; internal sac with a dark median structure.

Comparative notes: Based on the derived shapes and chaetotaxy of the male sternites VII-VIII and on the morphology of the aedeagus, $M$. sundaicus belongs to the M. ferrugineus group (see Assing 2013). It is distinguished from other species of this group by the shape and chaetotaxy of the male sternite VII, and by the shape of the aedeagus. In addition, it is characterized by rather small size, as well as the distinct microsculpture and fine punctation of the forebody.

Distribution and natural history: Medon sundaicus represents the first confirmed representative of the genus from the Oriental region and Indonesia. The record from Thailand should be considered tentative. The type specimens were collected in the type locality in Jawa Barat and in three localities in Sulawesi
Tengah and Sulawesi Utara, northern Sulawesi, by sifting forest litter, as well as with flight interception and Malaise traps. One specimen was collected from rotting fruit. Part of the type material from Sulawesi is slightly teneral.

\section{Medon sabahicus spec. nov.

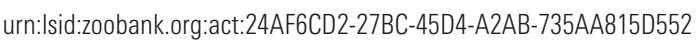 (Figs 22-25)}

Type material: Holotype $\sigma^{*}$ : "Malaysia, Sabah, Sandakan, S Lokan (LF) [= logged forest], March 97, AYC Chung / FIT 9/3/4 / Pae50 / BMNH \{E\} 2002-113, A. Y. C. Chung, LF - Logged Forest / Holotypus ${ }^{\star}$ Medon sabahicus sp. n. det. V. Assing 2015” (BMNH).

Etymology: The specific epithet (adjective) is derived from Sabah, where the type locality is situated.

Description: Body length $3.7 \mathrm{~mm}$; length of forebody $2.0 \mathrm{~mm}$. Elytra brown, with the humeral portion paler. Other external characters as in M. sundaicus.

$\sigma^{*}$ : sternite VII (Fig. 22) transverse, posterior margin with broad and pronounced concavity, on either side with a comb of 8 palisade setae; sternite VIII (Fig. 23) with a rather large posterior excision of subtriangular shape; aedeagus $0.51 \mathrm{~mm}$ long and shaped as in Figs 24-25.

Comparative notes: This species is distinguished from the similar M. sundaicus by slightly larger size, the darker coloration of the elytra, the differently shaped posterior margin of the male sternite VII with longer combs of more numerous palisade setae, and by the longer aedeagus with a differently shaped apex (ventral view) and without a dark internal structure.

Distribution and natural history: The type locality is situated in Sabah, northeastern Borneo, Malaysia. The holotype was collected with a flight interception trap in a logged forest.

\section{Medon fusculus group}

\section{Medon fusculus (MANNERHeim, 1830)}

Material examined: Georgia: 7 exs., Kakheti, Bakurtsikhe env., $41.68^{\circ} \mathrm{N}, 45.85^{\circ} \mathrm{E}, 480 \mathrm{~m}$, deciduous forest, sifted, 13.VII.2015, leg. Kocian (cKoc, cAss).

Comment: The expansive Ponto-Mediterranean distribution of $M$. fusculus ranges from the Caucasus region and the Middle East across Turkey, the Black Sea region, and the Balkans to France and South Britain (Assing 2013). 


\section{Medon lanugo Assing, 2004}

Material examined: Syria: 4 exs., Latakia province, $5 \mathrm{~km} \mathrm{~S}$ Kasab, pine forest, sifted, 5.VI.2010, leg. Kotán et al. (HNHM, cAss); 1 ex., Latakia province, $3 \mathrm{~km}$ S Kasab, pine forest, clearing, 2.VI.2010, leg. Kotán et al. (HNHM).

Comment: Medon lanugo had been recorded only from Turkey (Assing 2013). The above specimens represent the first records from Syria.

\section{Medon subfusculus Fagel, 1969}

Material examined: Turkey: 1 ex., Antalya, Alanya, 22 km E Demirtas, 100 m, 1.IV.1996, leg. Kopetz (NME); 1 ex., Antalya, Alanya, Dim Cay valley, Oteköy, 300 m, 3.IV.1996, leg. Kopetz (cAss).

Comment: This species is distributed in southern Anatolia and in the Greek island Kos (Assing 2013).

\section{Medon lindbergi Scheerpeltz, 1958}

Material examined: Lebanon: $1 \sigma^{\top}$ [det. Feldmann], ca. $30 \mathrm{~km}$ NE Beirut, bank of Ibrahim river near Adonis, 5.III.2014, leg. Reuter (cFel); $10^{\text {t }}$ [det. Feldmann], Rayfoun, ca. $33^{\circ} 58^{\prime} \mathrm{N}, 35^{\circ} 42^{\prime} \mathrm{E}$, mixed oak forest, ca. $990 \mathrm{~m}$, pitfall trap, 28.II-5.III.2017, leg. Reuter (cFel).

Comment: The distribution of M. lindbergi is confined to the Middle East from central southern Anatolia to Israel (Assing 2013).

\section{Medon sparsiventris EPPELSHEIM, 1889}

Material examined: Iran: Gilan: 13 exs., S Hashtpar, Asalem, 37 $42^{\prime} \mathrm{N}, 48^{\circ} 53^{\prime} \mathrm{E}, 110 \mathrm{~m}$, 9.X.2011, leg. Frisch (MNB, cAss); 4 exs., pass Khalkhal-Asalem, $37^{\circ} 36^{\prime} \mathrm{N}$, 4840'E, 2070 m, 13.X.2011, leg. Frisch (MNB, cAss).

Georgia: $30^{\star} \sigma^{\star}, 4$ ㅇ 우, Adjara, Skhalta valley, $41^{\circ} 35^{\prime} \mathrm{N}$, $42^{\circ} 22^{\prime} \mathrm{E}, 800 \mathrm{~m}, 22 . \mathrm{VI} .2017$, leg. Brachat \& Meybohm (cAss); $10^{\prime}$, Adjara, Skhalta valley, $41^{\circ} 34^{\prime} \mathrm{N}, 42^{\circ} 26^{\prime} \mathrm{E}$, 980 m, 22.VI.2017, leg. Brachat \& Meybohm (cAss); $10^{*}$, 1 ㅇ, Svaneti, $20 \mathrm{~km} \mathrm{~N}$ Jvari, $42^{\circ} 49^{\prime} \mathrm{N}, 42^{\circ} 02^{\prime} \mathrm{E}, 600 \mathrm{~m}$, 25.VI.2017, leg. Brachat \& Meybohm (cAss).

Comment: Medon sparsiventris had been reported from North Iran and Azerbaijan. The above specimens from Georgia represent new country records.

\section{Medon paradisiacus Assing, 2004}

Material examined: Armenia: $2 \sigma^{\star} \sigma^{\star}, 10 \mathrm{~km} \mathrm{~S}$ Kapan, SE Chakaten, $39^{\circ} 08^{\prime} \mathrm{N}, 46^{\circ} 28^{\prime} \mathrm{E}, 990 \mathrm{~m}$, mixed deciduous forest, litter and debris sifted, 9.VII.2016, leg. Assing (cAss).

Comment: This species was previously known only from Iran and Azerbaijan (Assing 2013). The above specimens represent the first record from Armenia.

\section{Medon frischi Assing, 2005}

Material examined: Iran: Chahar Mahal-o-Bakhtiyari:

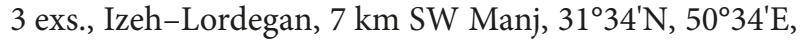
1250 m, 20.X.2011, leg. Frisch (MNB, cAss). Ilam: 8 exs., Ilam-Darreh Shar, $30 \mathrm{~km}$ NW Abher-e Bala, $33^{\circ} 27^{\prime} \mathrm{N}$, $46^{\circ} 47^{\prime} \mathrm{E}, 1080 \mathrm{~m}, 19 . \mathrm{X} .2011$, leg. Frisch (MNB, cAss); 1 ex., $10 \mathrm{~km} \mathrm{~S}$ Ilam City, $33^{\circ} 34^{\prime} \mathrm{N}, 46^{\circ} 25^{\prime} \mathrm{E}, 1300 \mathrm{~m}$, 19.X.2011, leg. Frisch (cAss).

Comment: The known distribution of M. frischi is confined to Iran (Assing 2013). The above records from Ilam represent a new province record.

\section{Medon sequax Assing, 2004}

Material examined: Georgia: 5 exs., Svaneti, Khuberi river valley, $42.86^{\circ} \mathrm{N}, 42.04^{\circ} \mathrm{E}, 720 \mathrm{~m}$, leaf litter sifted, 4.VII.2015, leg. Kocian (cKoc, cAss).

Comment: Medon sequax was previously known only from Armenia (Assing 2013). The above material represents the first record from Georgia.

\section{Medon fusculoides CoIfFAIt, 1970}

Material examined: Iran: Ilam: 15 exs., Ilam-Darreh

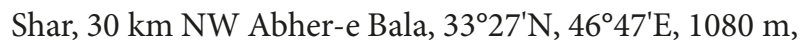
19.X.2011, leg. Frisch (MNB, cAss); 2 exs., 10 km S Ilam City, 333' N, 46 $25^{\prime} \mathrm{E}, 1300 \mathrm{~m}, 19 . X .2011$, leg. Frisch (cAss).

Comment: The distribution of this species ranges from eastern Anatolia to southeastern Iran; for a map see Assing (2009).

\section{Medon ripicola (KraATZ, 1854)}

Material examined: Spain: 2 exs., Galicia, Lugo, Folgoso do Courel env., car-net, 26.VI.2012, leg. Struyve (cFel). France: 2 우 우, Hérault, $1 \mathrm{~km} \mathrm{~N}$ Cabricri, $43^{\circ} 35^{\prime} \mathrm{N}, 3^{\circ} 22^{\prime} \mathrm{E}$, 120 m, 8.VI.2014, leg. Apfel (cApf). 
Comment: The above records are within the known distribution of $M$. ripicola.

\section{Medon umbilicatus CAMERON, 1924}

Material examined: Nepal: $1 \sigma^{\star}$, Seti, Bajhang district, way $17 \mathrm{~km} \mathrm{NE}$ Chainpur $\left(29^{\circ} 40^{\prime} \mathrm{N}, 81^{\circ} 19^{\prime} \mathrm{E}\right)$ to Dagaira Khola S Dhalaun $\left(29^{\circ} 41^{\prime} \mathrm{N}, 81^{\circ} 21^{\prime} \mathrm{E}\right), 1850-2000 \mathrm{~m}$, 7.VI.2009, leg. Weigel (NME).

Comment: Medon umbilicatus is the sole representative of the M. fusculus group in the East Palaearctic. It has been recorded from Pakistan, Kashmir, North India, and Nepal (Assing 2013).

\section{Medon profundus group}

\section{Medon profundus Assing, 2014}

Material examined: China: Sichuan: $2 \sigma^{\top} \sigma^{\star}, 8$ 우 우, Emei Shan, N29 33', E10321', $1730 \mathrm{~m}$, sifted, 25.V.2011, leg. Grebennikov (CAS, cSme, cAss); $10^{*}$, Emei Shan, $\mathrm{N} 29^{\circ} 34^{\prime}, \mathrm{E} 103^{\circ} 21^{\prime}, 1830 \mathrm{~m}$, sifted, 26.V.2011, leg. Grebennikov (cAss).

Comment: This recently described species has been recorded only from the Daba Shan and the Emei Shan, China (Assing 2014).

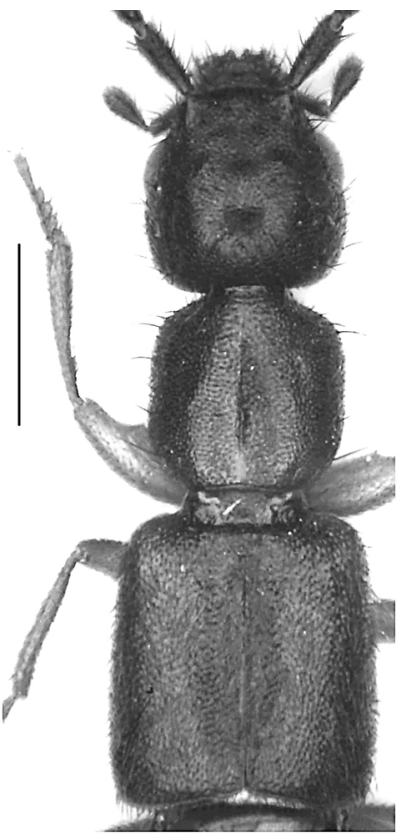

26

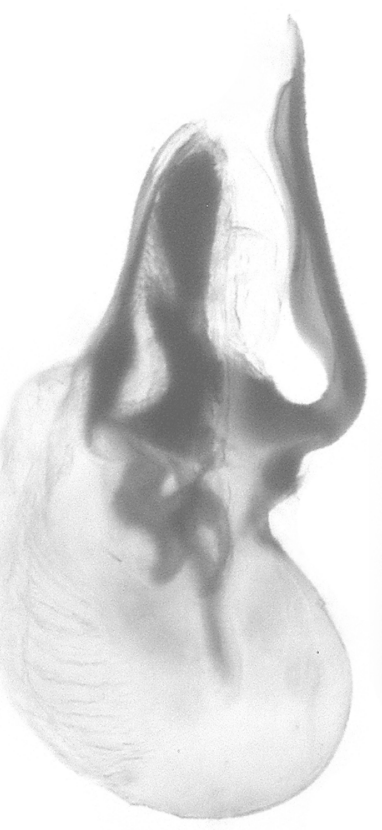

29

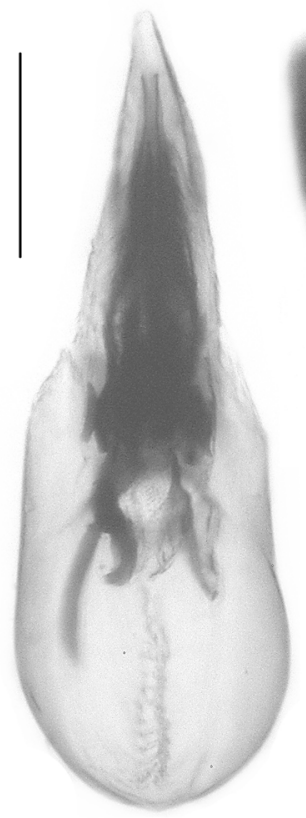

30

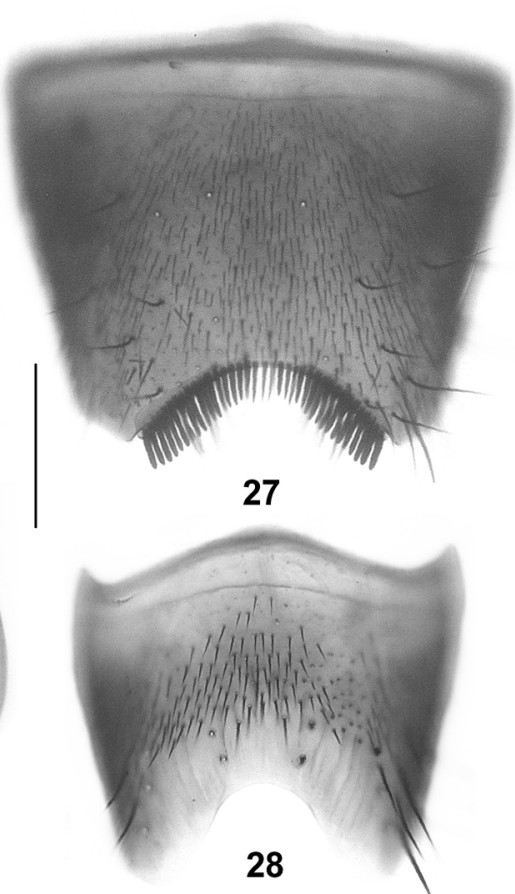

Figs 26-30: Medon emeianus spec. nov.: forebody (26); male sternite VII (27); male sternite VIII (28); median lobe of aedeagus in lateral and in ventral view (29-30). Scale bars: $26: 1.0 \mathrm{~mm}$; 27-30: $0.2 \mathrm{~mm}$. 
Head (Fig. 26) approximately as broad as long; punctation fine and dense; interstices with shallow microreticulation. Eyes large and rather weakly convex, 0.8-1.0 times as long as postocular region in dorsal view.

Pronotum (Fig. 26) 1.00-1.05 times as broad as long and 0.95-1.00 times as broad as head; anterior and posterior margins concave in the middle; punctation dense, fine (though less so than head), and granulose; midline with or without narrowly impunctate longitudinal band.

Elytra (Fig. 26) long and broad, approximately 1.25 times as long as pronotum; punctation fine, very dense, and weakly granulose. Hind wings fully developed. Abdomen narrower than elytra; punctation extremely fine and dense; interstices with shallow microreticulation; posterior margin of tergite VII with palisade fringe.

$\mathrm{o}^{\text {T: }}$ : sternite VII (Fig. 27) with large and concave posterior excision, margin of this excision furnished with a distinct comb of numerous long palisade setae and laterally with additional long black setae; sternite VIII (Fig. 28) small in relation to sternite VII, transverse, and with shallow median impression, this impression with black setae, posterior excision moderately deep and moderately broad; aedeagus (Figs 29-30) approximately $0.8 \mathrm{~mm}$ long; ventral process of characteristic shape; internal sac with dark structures in characteristic arrangement.

Comparative notes: Based on the derived shapes and chaetotaxy of the male sternites VII-VIII and on the synapomorphically modified morphology of the aedeagus, M. emeianus undoubtedly belongs to the $M$. profundus group (see Assing 2014). It is distinguished from the sympatric $M$. profundus, which too has been recorded from Emei Shan, by darker coloration of the antennae, slightly smaller average body size, a less deep posterior excision of the male sternite VII, a smaller posterior excision and the different chaetotaxy of the male sternite VIII, and by the differently shaped ventral process and internal structures of the aedeagus. For illustrations of $M$. profundus and other species of the M. profundus group see Assing (2014).

Distribution and natural history: The type locality is situated in Emei Shan, Sichuan, at an altitude of approximately $1460 \mathrm{~m}$.

\section{Acknowledgements}

I am indebted to the colleagues indicated in the material section for the loan of material under their care. Benedikt Feldmann (Münster) proof-read the manuscript.

\section{References}

Assing, V. 2004a: A revision of the Medon species of the Eastern Mediterranean and adjacent (Insecta: Coleoptera: Staphylinidae: Paederinae). - Bonner Zoologische Beiträge 52 $(1,2)$ : 33-82. _http:// www.zoologicalbulletin. de $/ \mathrm{B} z \mathrm{~B}$ Volumes

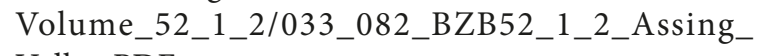

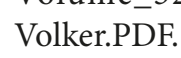

Assing, V. $\overline{2}$ 004b: A revision of Western Palaearctic Medon Stephens (Coleoptera: Staphylinidae, Paederinae). Supplement I. - Linzer biologische Beiträge 36 (2): 655-662. - - https://www.zobodat.at/pdf// LBB 0036 2_0655-0662.pdfi

Assing, V. $200 \overline{5}$ : A revision of Western Palaearctic Medon. IV. A new species and new records from Iran, and a catalogue of species (Coleoptera: Staphylinidae, Paederinae). - Linzer biologische Beiträge 37 (2): 1027-1034. - htttps://www.zobodat.at/pdf/LBB_0037' 2_1027-1034.pdfi.

Assing, V. 2006: A' revision of Western Palaearctic Medon: the species of the Atlantic Islands, the Western Mediterranean, and Europe, except for the southeast (Insecta: Coleoptera: Staphylinidae: Paederinae). Bonner Zoologische Beiträge 54 (2005) (1-2):25-95. - _ htttp://www.zoologicalbulletin.de/BzB Volumes/i

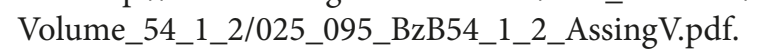

Assing, V. $2007 \mathrm{a}$ : $\mathrm{A}$ revision of Western Palaearctic Medon. V. A new species from Iran and additional records (Coleoptera: Staphylinidae, Paederinae) _Linzer biologische Beiträge 39.(1): 23-32. - https://' www.zobodat.at/pdf/LBB_0039_1_0023-0032.pdfi

Assing, V. $2007 \mathrm{~b}$ : A revision of Western Palaearctic Medon. VI. A new species from Turkey and additional records (Coleoptera: Staphylinidae, Paederinae) _Linzer biologische Beiträge 39 (2): 791-797 _ htttps:// www.zobodat.at/pdf/LBB_0039_2_0791-0797.pdfi

Assing, V. 2009: A revision of Western Palaearctic Medon. VII. A new species from southern Turkey and additional records (Coleoptera: Staphylinidae: Paederinae). -_ Linzer biologische _ Beiträge 41 (2): 1253-1268. - hhttps://www.zobodat.at/pdf/LBB_0041' $2-1253-1268 . p d f$

Assing, V. 2010: A revision of Palaearctic Medon. VIII. A new species from Nepal and additional records (Coleoptera: Staphylinidae: Paederinae). -_ Linzer biologische Beiträge 42 (1): 489-498. - "https://www.' 'zobodat.at/pdf/LBB_0042_1_0489-0498.pdft.

Assing, V. 2013 : A revision of Palaearctic Medon IX. New species, new synonymies, a new combination, and additional records (Coleoptera: Staphylinidae: Paederinae). - Entomologische Blätter und Coleoptera 109: 233-270. 
Assing, V. 2014: Three new species and a new species group of Medon from China and Taiwan (Coleoptera: Staphylinidae: Paederinae) ; - _Linzer biologische Beiträge 46 (1): 515-523.- - https://www.zobodat.at// pdf/LBB_0046_1_0515-0523.pdff.

Assing, V. 2016 : On the Stphylinidae of the Greek island Karpathos (Insecta: Coleoptera) : _ Linzer biologische Beiträge 48 (1): 235-263. - https://www.zobodat.at/1 pdf/LBB_0048_1_0235-0263.pde.

Assing, V.; SCHÜLKe, M.; BRACHAT, V. \& МeYbohm, H. 2018: On the Staphylinidae of the Greek island Corfu (Insecta: Coleoptera). - Contribution to Entomology 68 (1): 31-67.
Schülke, M. \& Smetana, A. 2015: Staphylinidae, pp. 304-1134. - In: LöBL, I. \& LöBL, D. (eds), Catalogue of Palaearctic Coleoptera. New, updated Edition. Volume 2. Hydrophiloidea - Staphylinoidea. Revised and updated edition. - Leiden: Brill: xxvi + $1702 \mathrm{pp}$.

Shibata, Y. \& Fujimoto, H. 2017: A new intertidal species of the genus Medon (Coleoptera, Staphylinidae, Paederinae) from Kagawa, Japan. - Elytra, Tokyo, New Series 7 (1): 55-60. 